\title{
Localization and Developmental Expression of the NMDA Receptor Subunit NR2A in the Mammalian Retina
}

\author{
E. HARTVEIT, J.H. BRANDSTÄTTER, M. SASSOÈ-POGNETTO, \\ D.J. LAURIE, P.H. SEEBURG, AND H. WÄSSLE \\ Max-Planck-Institut für Hirnforschung, Neuroanatomische Abteilung, D-60528 Frankfurt, \\ Federal Republic of Germany (E.H., J.H.B., M.S.-P., H.W.); Laboratorium für Molekulare \\ Neuroendokrinologie, ZMBH, Universität Heidelberg, D-69120 Heidelberg, \\ Federal Republic of Germany (D.J.L., P.H.S.)
}

\begin{abstract}
The localization of the N-methyl-D-aspartate receptor subunit NR2A was studied, by using light microscopic immunocytochemistry, in the retina of adult rat, rabbit, cat, and monkey. Strong, punctate immunolabeling was observed in the inner plexiform layer indicating a synaptic localization of the NR2A subunit. The punctate labeling was concentrated in two bands corresponding to the on- and off-sublaminae of the inner plexiform layer.

The punctate character of immunofluorescence suggested a synaptic localization of the receptor. This was confirmed by electron microscopy of immunostained adult rat retina. The staining was localized postsynaptic to cone bipolar cells, and only one of the two postsynaptic elements of the dyad was labeled. Staining was not observed at extrasynaptic plasma membranes.

In situ hybridization of adult rat retina showed expression of the NR2A subunit in virtually all ganglion cells and displaced amacrine cells in the ganglion cell layer and in a subset of amacrine cells in the inner nuclear layer.

The postnatal developmental expression of the NR2A subunit was studied in rat retina by light microscopic immunocytochemistry. Punctate immunolabeling appeared prior to eye opening, and the developmental profile of NR2A could be compatible with a role in development of circuitry in the inner plexiform layer. 1994 Wiley-Liss, Ine.
\end{abstract}

Key words: cat retina, glutamate receptors, monkey retina, rabbit retina, rat retina

In the retina, there is strong evidence that glutamate is the neurotransmitter of the vertical signal pathway, both at the photoreceptor-to-bipolar cell synapse in the outer plexiform layer (OPL; Copenhagen and Jahr, 1989) and at the bipolar cell-to-ganglion cell synapse in the inner plexiform layer (IPL; Tachibana and Okada, 1991). In addition, glutamate released from photoreceptors and bipolar cells also acts on horizontal cells in the OPL and on amacrine cells in the IPL, respectively (for review, see Massey, 1990). Pharmacological investigations have revealed that there are three major classes of ionotropic glutamate receptors (reviewed by Monaghan et al., 1989) defined by selective interaction with their specific agonists $\mathrm{N}$-methyl-D-aspartate (NMDA), $\alpha$-amino-3-hydroxy-5-methyl-4-isoxazolepropionate (AMPA), and kainate. AMPA and kainate receptors are often collectively referred to as non-NMDA receptors. Glutamate also acts at different metabotropic receptors that mediate their effects through guanosine triphosphatebinding proteins (Monaghan et al., 1989). Two metabo- tropic receptors have been defined pharmacologically by interaction with their respective agonists (1S,3R)-1-aminocyclopentane-1,3-dicarboxylic acid (ACPD) and aminophosphonobutyrate (APB).

There is evidence that all these types of glutamate receptor are present at various locations in the retinal circuitry (reviewed by Massey, 1990). Due to their unique biophysical and pharmacological properties, such as $\mathrm{Mg}^{2+}$ dependent voltage block (Nowak et al., 1984), $\mathrm{Ca}^{2+}$ permeability (MacDermott et al., 1986), potentiation by glycine (Johnson and Ascher, 1987), and slow kinetics (Collingridge et al., 1988; Forsythe and Westbrook, 1988), particular attention has been devoted to the NMDA receptors, which seem to be involved in neuronal signalling in the IPL

\footnotetext{
Accepted May 10, 1994.

Address reprint requests to Heinz Wässle, Max-Planck-Institut f. Hirnforschung, Neuroanatomische Abteilung, Deutschordenstrasse 46, D-60528 Frankfurt a.M., Federal Republic of Germany.
} 
(Slaughter and Miller, 1983b; Aizenman et al., 1988; Coleman and Miller, 1988; Massey and Miller, 1988, 1990; Boos et al., 1990; Mittman et al., 1990; Linn and Massey, 1991; Dixon and Copenhagen, 1992; Gottesman and Miller, 1992).

Recently, it has become clear that, for each pharmacologically defined type of glutamate receptor, there is considerable heterogeneity at the molecular level. Several groups have cloned and characterized a large series of different subunits of non-NMDA receptors (Hollmann et al., 1989; Keinänen et al., 1990; Bettler et al., 1990; Boulter et al., 1990; Nakanishi et al., 1990; Egebjerg et al., 1991; Werner et al., 1991; Bettler et al., 1992; Herb et al., 1992), metabotropic receptors (Houamed et al., 1991; Masu et al., 1991; Tanabe et al., 1992), and NMDA receptors (Moriyoshi et al., 1991; Ikeda et al., 1992; Kutsuwada et al., 1992; Meguro et al., 1992; Monyer et al., 1992; Ishii et al., 1993). In expression systems, different combinations of subtypes give rise to glutamate receptors with markedly different biophysical and pharmacological properties (Boulter et al., 1990; Keinänen et al., 1990; Nakanishi et al., 1990; Hollmann et al., 1991; Burnashev et al., 1992; Herb et al., 1992; Ikeda et al., 1992; Kutsuwada et al., 1992; Meguro et al., 1992; Monyer et al., 1992; Ishii et al., 1993), and it is assumed that different subunits coassemble in different combinations to form heterooligomeric receptors.

It is not clear which NMDA receptor subunits are employed in the retinal circuitry. The expression of NMDA and non-NMDA receptor subunits has been studied by in situ hybridization to the respective mRNA species (Hughes et al., 1992; Müller et al., 1992; Hamassaki-Britto et al., 1993; Brandstätter et al., 1994; Watanabe et al., 1994). At best, however, in situ hybridization can only show that a given cell expresses a specific set of different receptor subunit mRNAs (Hamassaki-Britto et al., 1993). It cannot be used to determine where in the cell the corresponding receptor subunits are localized, and it does not show which subunits are localized together in the complex that constitutes the functional receptor. These limitations can be overcome by employing specific antibodies against the receptor subunits. As a first step toward understanding the role of NMDA receptors at a molecular level in the retinal synaptic circuitry, we report here on the expression and localization of the NMDA receptor subunit NR2A (Kutsuwada et al., 1992; Meguro et al., 1992; Monyer et al., 1992) in mature and developing retina as examined by in situ hybridization and light and electron microscopic immunocytochemistry.

\section{MATERIALS AND METHODS Generation of monoclonal antibody}

Monoclonal antibody 2F6.3D5 was raised against a Cterminal sequence of the rat NMDA receptor subunit NR2A. In brief, the nucleotide sequence encoding amino acids 886-1,029 (NR2A.C1C2) was amplified via polymerase chain reaction (PCR) and subcloned into the bacterial expression vector pRSET7a (Schoepfer, 1993). The bacterial strain BL21.DE3.pLysS was transformed with the plasmid, and production of the protein was induced by 0.4 mM isopropyl- $\beta$-thiogalactopyranoside (Studier et al., 1990). After purification, the NR2A.C1C2 polypeptide was used to immunize mice and generate monoclonal antibody cultures (performed by K. Naujoks and I. Bartke, Boehringer Mannheim, Federal Republic of Germany). The specificity of the 2F6.3D5 antibody was assessed by immunoblotting of rat forebrain proteins (Amersham ECL). The antibody was employed as a 1:2,000 dilution of tissue culture supernatant in $10 \%$ bovine serum albumin $/ 0.01 \mathrm{M}$ phosphatebuffered saline (PBS). On Western blots of rat forebrain proteins, the 2F6.3D5 monoclonal antibody labeled a band of $163 \mathrm{kDa}$ (Fig. 1A), which corresponds closely to the predicted molecular weight of the NR2A subunit (approximately $160 \mathrm{kDa}$; Monyer et al., 1992). Labeling was prevented by coincubation with $10 \mu \mathrm{g}$ of the antigenic polypeptide (Fig. 1A). This antibody also labeled a similar band in Western blots of NR2A-transfected human embryonic kidney (HEK) 293 cell proteins, labeled only NR2A-transfected HEK 293 cells in immunofluorescence experiments (not NR2B-, NR2C-, or NR2D-transfected cells) and, in peroxidase immunohistochemical experiments, indicated a distribution of the antigen in rat brain (not shown) very similar to that of the NR2A mRNA (Monyer et al., 1992).

\section{Immunocytochemistry}

For light microscopy, young [postnatal day (P)4-P23] and adult albino rats were deeply anesthetized with halothane $\left(4 \%\right.$ in $\left.\mathrm{O}_{2}\right)$ and decapitated. The eyes were removed and opened along the ora serrata by an encircling cut. The cornea, lens, and vitreous body were removed, and the posterior eyecup was fixed by immersion in $4 \%$ paraformaldehyde in phosphate buffer (PB; $0.1 \mathrm{M}, \mathrm{pH} 7.4$ ) for 4-60 minutes. Recognition of the antigen by 2F6.3D5 was very sensitive to fixation, and the best results for adult animals, taking into account both preservation of histological structure and intensity of staining, were obtained with fixation times of about 10 minutes. Because the labeling was very weak in the youngest animals, the fixation time was reduced to 4-5 minutes in this part of the study.

After fixation, the retina was carefully dissected out of the eyecup and cryoprotected by immersing in PB with increasing sucrose concentrations $(5-30 \%)$ overnight at $4^{\circ} \mathrm{C}$. Vertical sections $(14 \mu \mathrm{m})$ were cut on a cryostat and collected on silanized and glutaraldehyde-activated slides.

The cat, rabbit, and macaque monkey eyes were obtained from animals used in other experiments. The animals were all deeply anesthetized with pentobarbitone sodium. For cat and rabbit, the rest of the procedure was as for the rats. The monkey was transcardially perfused with $4 \%$ paraformaldehyde in $\mathrm{PB}$, and the eyes were removed after 10 minutes of perfusion. The retina was dissected from the posterior eyecup without further fixation, washed in $\mathrm{PB}$, and cryoprotected as described above.

For immunolabeling, the sections were rinsed two times for 10 minutes each in PBS and preincubated in PBS with $10 \%$ normal goat serum (NGS) and $0.5 \%$ Triton X-100 for 1 hour. Thereafter, the sections were incubated overnight with the primary antibody diluted 1:20 or 1:100 in PBS with $3 \%$ NGS, $0.5 \%$ Triton $\mathrm{X}-100$, and $0.05 \%$ sodium azide. The sections were then rinsed three times for 10 minutes each in PBS, incubated with the secondary antibody (goat anti-mouse IgG coupled to CY3 (carboxymethylindocyanine; Dianova, Federal Republic of Germany), and washed again in PBS. Finally, the sections were embedded in Mowiol (Hoechst, Federal Republic of Germany) and examined under epifluorescence.

For the developmental study, pilot experiments were carried out on animals at various ages taken from different litters. In the more detailed analysis, animals from the same litter were killed at daily intervals. This procedure was carried out for three different litters $\left(\mathrm{n}_{1}=15, \mathrm{n}_{2}=7\right.$, 


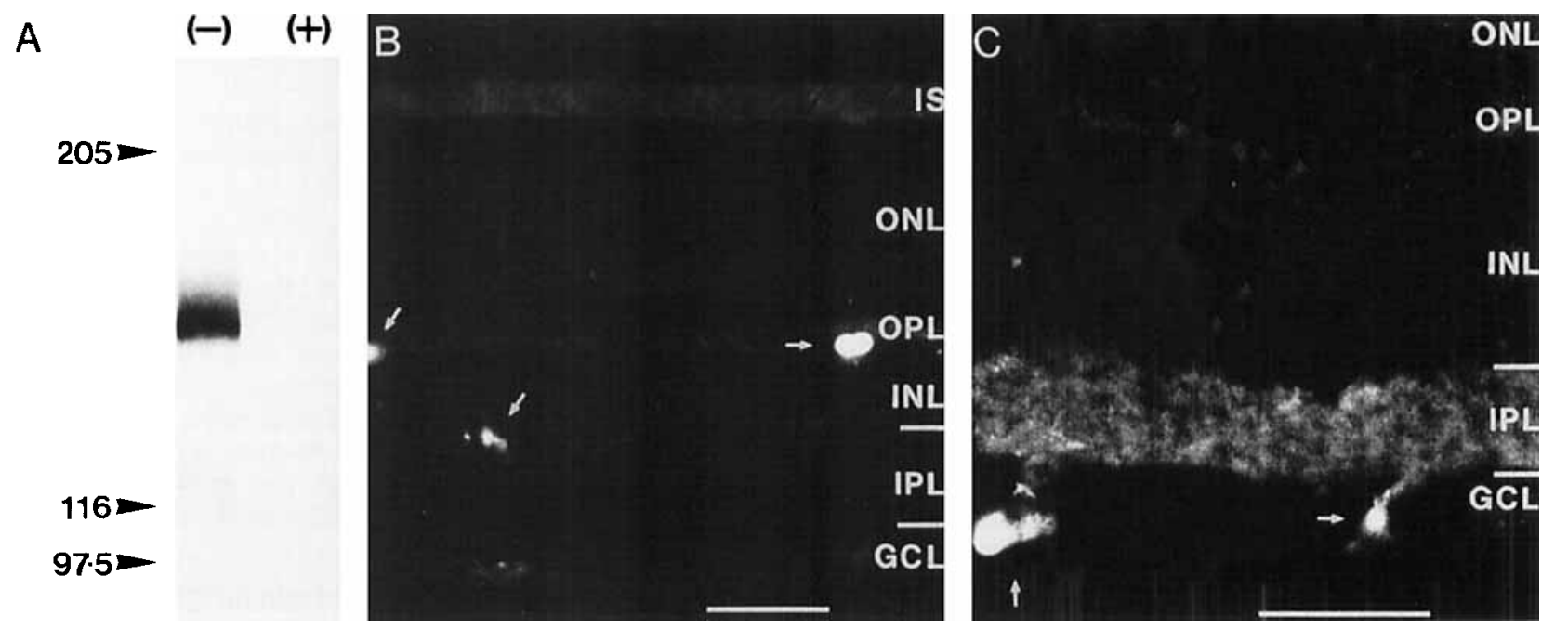

Fig. 1. A: Western blot of rat forebrain proteins probed with the 2F6.3D5 antibody. ( - ) and $(+)$ indicate the absence and presence, respectively, of the antigenic polypeptide NR2A.C1C2 in the incubation solution. B,C: Absence of punctate immunofluorescence in vertical cryostat sections of rat retina [B: adult; C: postnatal day (P)10], when

$\mathrm{n}_{3}=7$ ). For all litters, the day of birth was observed by one of the authors and was taken as P0.

Control sections were processed as described above, except that the first antibody was omitted. In the adult animals, the background labeling in the IPL was very weak (Fig. 1B). In the young, postnatal animals, there was stronger, diffuse immunofluorescence in the IPL but never of a punctate character (Fig. 1C). We do not know why the background labeling in the IPL was stronger during development than in the adult. For unknown reasons, we also found labeling of photoreceptor inner segments and blood vessels (Fig. 1B,C). This is often observed in immunocytochemical investigations of the retina.

For electron microscopy, the same procedure for immersion fixation as described above for light microscopy was used, except that the fixation time was prolonged to 30 minutes and picric acid was added at a concentration of $0.2 \%$. This relatively long fixation time strongly reduced the intensity of labeling as observed in the light microscope, but shorter fixation times were not compatible with electron microscopic examination. After cryoprotection with sucrose in $\mathrm{PB}$, small pieces of tissue were repeatedly frozen and thawed, embedded in agar, and sectioned vertically at 70 $\mu \mathrm{m}$ on a vibratome. Free-floating sections were collected in cold PBS, immersed for 2 hours in 10\% NGS in PBS, and then incubated in the primary antibody diluted $1: 100$ in the same dilution medium used for light microscopy (omitting Triton X-100) for 4 days at room temperature. Thereafter, the sections were rinsed in PBS (three times for 10 minutes each) and incubated for 2 hours at room temperature in biotinylated sheep anti-mouse IgG (Amersham, Federal Republic of Germany; 1:100), rinsed again in PBS, and transferred to a solution containing the extravidin-peroxidase complex (Sigma, Federal Republic of Germany; 1:100) for 1 hour at room temperature. After rinses in PBS and in $0.05 \mathrm{M}$ Tris- $\mathrm{HCl}(\mathrm{pH}$ 7.6), the sections were reacted in $3,3^{\prime}$-diaminobenzidine (DAB; $0.05 \%$ in $0.05 \mathrm{M}$ Tris- $\mathrm{HCl}, \mathrm{pH}$ 7.6) with $0.01 \% \mathrm{H}_{2} \mathrm{O}_{2}$ for 10 minutes. Subsequently, the sections were rinsed in $0.1 \mathrm{M}$ cacodylate buffer ( $\mathrm{pH} 7.4$ ), the primary antibody (2F6.3D5) was omitted. Borders of the inner plexiform layer are indicated by horizontal lines. Arrows point to stained blood vessels. IS, inner segments of photoreceptors; ONL, outer nuclear layer; OPL, outer plexiform layer; INL, inner nuclear layer; IPL, inner plexiform layer; GCL, ganglion cell layer. Scale bars $=30 \mu \mathrm{m}$.

postfixed in glutaraldehyde $(2.5 \%$ in cacodylate buffer; 2 hours at $4^{\circ} \mathrm{C}$ ), and washed in cacodylate buffer overnight at $4^{\circ} \mathrm{C}$. The $\mathrm{DAB}$ reaction product was silver intensified and treated with $0.05 \%$ gold chloride (Sigma) using a modified version of a procedure described previously (Leranth and Pickel, 1989). The sections were then postfixed with $2 \%$ $\mathrm{OsO}_{4}$ in cacodylate buffer for 1 hour, dehydrated in a graded series of acetone $(30-100 \%)$, and flat-embedded in Epon 812 (Serva, Federal Republic of Germany). Serial ultrathin sections were stained with uranyl acetate and lead citrate and examined with an EM 10 electron microscope (Zeiss, Federal Republic of Germany).

\section{In situ hybridization}

Adult rats were anesthetized with pentobarbitone sodium (i.p.) and fixed by transcardial perfusion with $250 \mathrm{ml}$ 4\% paraformaldehyde in PB. The eyes were enucleated, the cornea, lens, and vitreous body were removed by an encircling cut along the ora serrata, and the eyecups were postfixed in the same fixative with 5\% sucrose added for 1 hour. They were then washed in PB with $10 \%$ sucrose for 1 hour, and the retina was carefully dissected out of the eyecup and cryoprotected with $30 \%$ sucrose in PB for $2-3$ hours. Vertical sections were cut at $14 \mu \mathrm{m}$ on a cryostat and collected on silanized and glutaraldehyde-activated slides. Sections were postfixed for 5 minutes in $4 \%$ paraformaldehyde in $\mathrm{PB}$ containing $0.1 \%$ diethylpyrocarbonate (DEPC), washed in PB with $0.1 \% \mathrm{DEPC}$, and treated for 10 minutes in $0.9 \% \mathrm{NaCl}$ with $0.1 \mathrm{M}$ triethanolamine and $0.25 \%$ acetanhydride. Finally, the sections were dehydrated in graded ethanol series and stored in $95 \%$ ethanol at $4^{\circ} \mathrm{C}$ until hybridization. Before hybridization, the sections were air dried and defatted in chloroform for 5 minutes.

Hybridization was performed as described by Wisden et al. (1991). A 45-mer nucleotide antisense probe was labeled 3 '-end using $\left[\alpha^{35} \mathrm{~S}\right] \mathrm{dATP}(1,200 \mathrm{Ci} / \mathrm{mmol}$; DuPont $)$ and terminal transferase (Boehringer Mannheim). The probe was the same as that used by Monyer et al. (1992). 
Hybridization was performed at $42^{\circ} \mathrm{C}$ overnight in hybridization buffer [ $50 \%$ formamide, $4 \times$ standard saline citrate (SSC; $1 \times \mathrm{SSC}=0.15 \mathrm{M}$ sodium chloride, $0.015 \mathrm{M}$ sodium citrate), $10 \%$ dextran sulfate]. After hybridization, sections were washed twice for 20 minutes in $1 \times \mathrm{SSC}$ at $55^{\circ} \mathrm{C}$. The slides were then dipped in Ilford L-4 emulsion and stored with desiccant at $4^{\circ} \mathrm{C}$ for 10-12 weeks. After exposure, the slides were developed in Kodak D19, washed, fixed, and counterstained with toluidine blue before being dehydrated in a graded series of ethanol and coverslipped with Permount (Fisher Scientific, Fair Lawn, NJ). Incubation with a 20 -fold excess of unlabeled probe in addition to labeled probe resulted in no detectable signal (cf. Müller et al., 1992). The expression of NR2A in rat brain has been documented with the same probe by Monyer et al. (1992), and we routinely hybridized brain sections as positive controls. The sections were cut sagittally at $18 \mu \mathrm{m}$ from freshly frozen brains and processed in the same way as the retina sections.

\section{RESULTS \\ Immunocytochemical localization of the NR2A subunit in rat retina}

Labeling obtained with the 2F6.3D5 antibody was characterized by strong, distinctly punctate fluorescence distributed throughout the IPL. The intensity of labeling was stronger in two relatively broad bands in the upper twothirds of the IPL (Fig. 2A). The upper band was located close to the inner nuclear layer, and the lower band was slightly below the middle of the IPL. Between the two bands, there was a region of weaker immunoreactivity. At some locations, the outermost band was subdivided into two regions of higher density of punctate labeling, but there was always some label between these two subregions. Below the innermost labeled band, the intensity of the immunolabeling decreased and reached very low levels in the innermost part of the IPL, close to the ganglion cell layer. Most likely, this corresponds to the area of termination of axons from rod bipolar cells (Chun et al., 1993), suggesting that the NR2A subunit is not involved in the output from these cells. In no cases did we observe punctate immunofluorescence in the OPL.

\section{Immunocytochemical localization of the NR2A subunit in rabbit, cat, and monkey retina}

With a few differences, the general pattern of labeling in rabbit, cat, and monkey strongly resembled that in the rat (Fig. 2B-D). In the rabbit retina (Fig. 2B), the band-like pattern of the punctate label was more pronounced than in the rat (Fig. 2A), but there was no evidence of a substructure, i.e., that each band could be divided into subregions.

In the cat retina (Fig. 2C), labeling in the IPL was also of a distinctly punctate character, but the demarcation into two bands was not as pronounced as for rat (Fig. 2A) and rabbit (Fig. 2B). The intensity of labeling was, however, perceptibly lower in the innermost part of the IPL. The major distinctive feature of immunolabeling in cat retina, compared with rat, rabbit, and monkey, was the occurrence of sparse and irregularly distributed, but still distinct, punctate labeling in the OPL (Fig. 2C). This was never observed in any of the control sections and was well differentiated from nonspecific labeling corresponding to blood vessels. Another unique feature of the cat retina was the clear labeling of the outer limiting membrane in the experimental, but not in the control, sections (not shown), suggesting that the antibody may cross-react with an unknown antigen. Similar labeling has also been observed with antibodies against glycine receptors (Grünert and Wässle, 1993).

The macaque monkey retina displayed strong punctate labeling in the IPL (Fig. 2D). The organization in two bands was quite pronounced, comparable to the rabbit retina.

\section{Electron microscopic localization of the NR2A subunit in rat retina}

The punctate character of the immunofluorescence seen in light microscopy indicated that the NR2A subunit is distributed in an aggregate pattern, suggesting a synaptic localization. In order to investigate this more closely, we examined the ultrastructural localization of the NR2A subunit by electron microscopic immunocytochemistry. The major findings were that the staining was localized at synaptic regions, that it was postsynaptic to cone bipolar terminals in the outer two-thirds of the IPL, and that only one of the two postsynaptic elements in each dyad (Dowling and Boycott, 1966; Dubin, 1970) was stained. More than 30 NR2A-immunoreactive synapses were observed; all were cone bipolar cell dyads (determined from their relative location in the IPL), and no conventional synapses were found to be immunoreactive. Both examples in Figure 3A,B show a cone bipolar terminal forming a ribbon synapse with two profiles that constitute the dyad. Silver-intensified $\mathrm{DAB}$ reaction product can clearly be seen in one of the postsynaptic profiles, where it is located at the cytoplasmic face of the postsynaptic membrane density. In no case did we observe extrasynaptic localization of the reaction product, i.e., reaction product located at the plasma membrane but outside the synaptic region. Typically, some reaction product could be observed in the cytoplasm near the postsynaptic membrane density. We do not know whether this represents diffusion of reaction product or labeling of antigen present in the cytoplasm. The postsynaptic process without reaction product contained a large number of synaptic vesicles (Fig. 3A,B). On this basis, it could be securely identified as belonging to an amacrine cell (Dowling and Boycott, 1966; Dubin, 1970; Kolb, 1979). The labeled process did not contain vesicles and is therefore most likely a ganglion cell dendrite (Fig. 3A,B). Similar results were seen for other dyads postsynaptic to cone bipolar cells. With our material, fixed for only 30 minutes, it was not always possible to identify clear synaptic vesicles in one of the postsynaptic profiles, a necessary condition for identifying it as belonging to an amacrine cell. It is therefore possible that some of the stained profiles belong to amacrine cells.

\section{Localization of mRNA for the NR2A subunit}

The results from light and electron microscopic immunocytochemistry suggested expression of the NR2A subunit by cells with processes in the IPL. The localization and character of the labeled bands in the IPL could not by itself directly answer the question concerning which cells express this subunit. We therefore performed in situ hybridization with an oligonucleotide probe specific for the NR2A subunit mRNA. The results suggested that the NR2A subunit is expressed by virtually all cells of the ganglion cell layer (ganglion cells and displaced amacrine cells) as well as by some cells in the inner part of the inner nuclear layer (INL), 

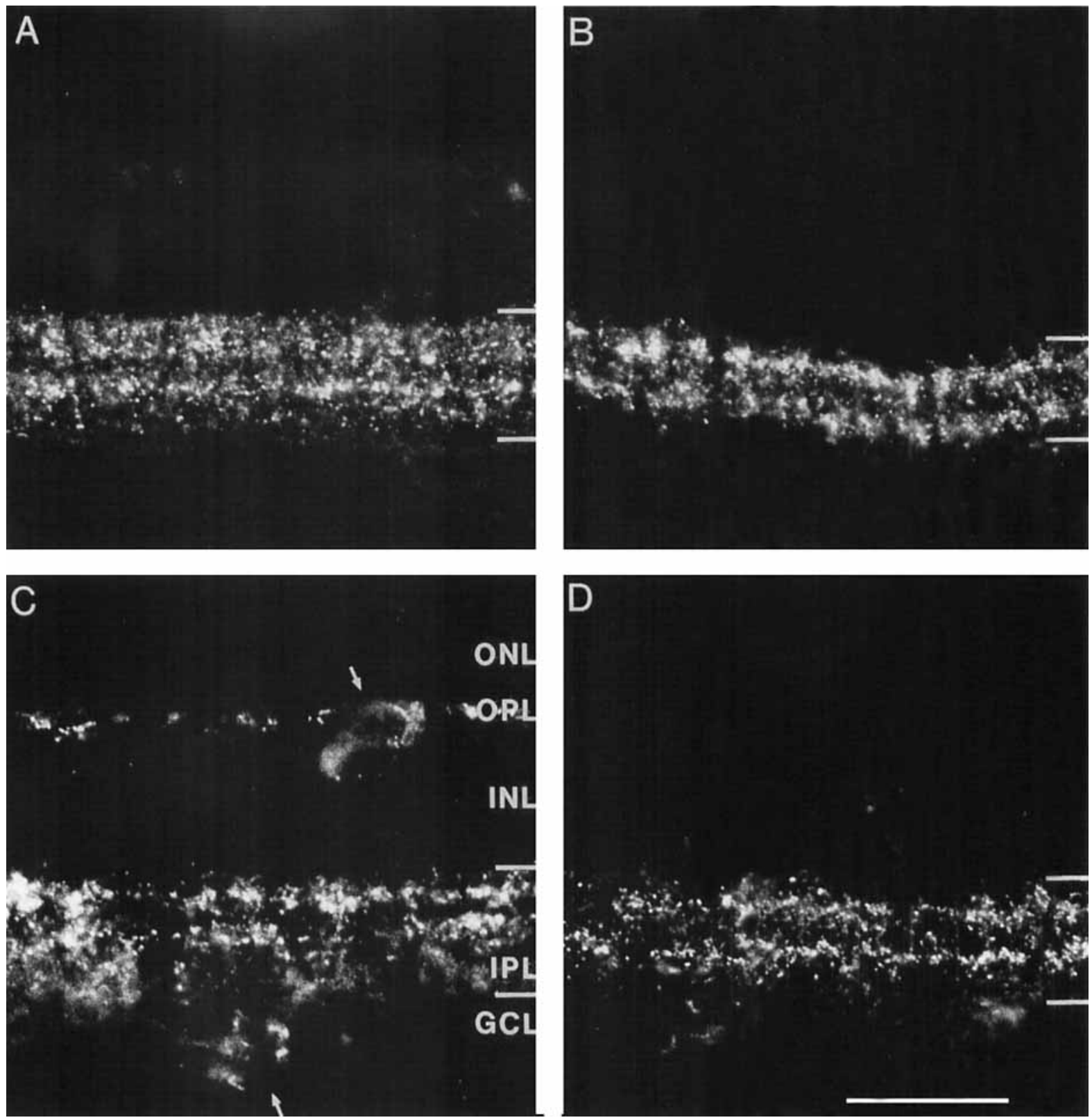

Fig. 2. Localization of NMDA receptor subunit NR2A immunoreactivity in vertical cryostat sections of rat $(\mathbf{A})$, rabbit $(\mathbf{B})$, cat $(\mathbf{C})$, and monkey (D) retina. In all species, strong punctate immunofluorescence is concentrated in two major bands in the inner plexiform layer. In the cat retina $(\mathrm{C})$, there is also sparsely distributed punctate labeling in the

i.e., closest to the IPL (Fig. 4A). Based on their relative location in the INL, these cells are most likely amacrine cells. Furthermore, the label in the INL was discontinuous and distributed in patches with clear examples of unlabeled cells between the labeled ones. This strongly suggests that only a subset of amacrine cells expresses the NR2A subunit.

\section{Development of the NR2A subunit in rat retina}

Taken together, the expression and localization of the NMDA receptor NR2A subunit in the adult rat, rabbit, cat, and monkey strongly suggest that this receptor is involved in synaptic transmission from cone bipolar cells to ganglion

outer plexiform layer. Borders of the inner plexiform layer are indicated by horizontal lines. Arrows point to stained blood vessels. ONL, outer nuclear layer; OPL, outer plexiform layer; INL, inner nuclear layer; IPL, inner plexiform layer; GCL, ganglion cell layer. Scale bar $=30 \mu \mathrm{m}$.

cells and a subset of amacrine cells. As a next step, the development of immunoreactivity for the NR2A subunit was examined in relation to the development of the retina, in particular to the period of synaptogenesis in the IPL. We were interested to see whether the appearance of the NR2A subunit would suggest a role in the development of the circuitry in the IPL, in particular, whether the intensity of immunofluorescence in the IPL would increase in a monotonic fashion, or whether it would be higher at some developmental stage than in the adult.

During the postnatal period from $\mathrm{P} 4$ (the earliest day examined) to $\mathrm{P} 9$, no specific, punctate labeling could be 

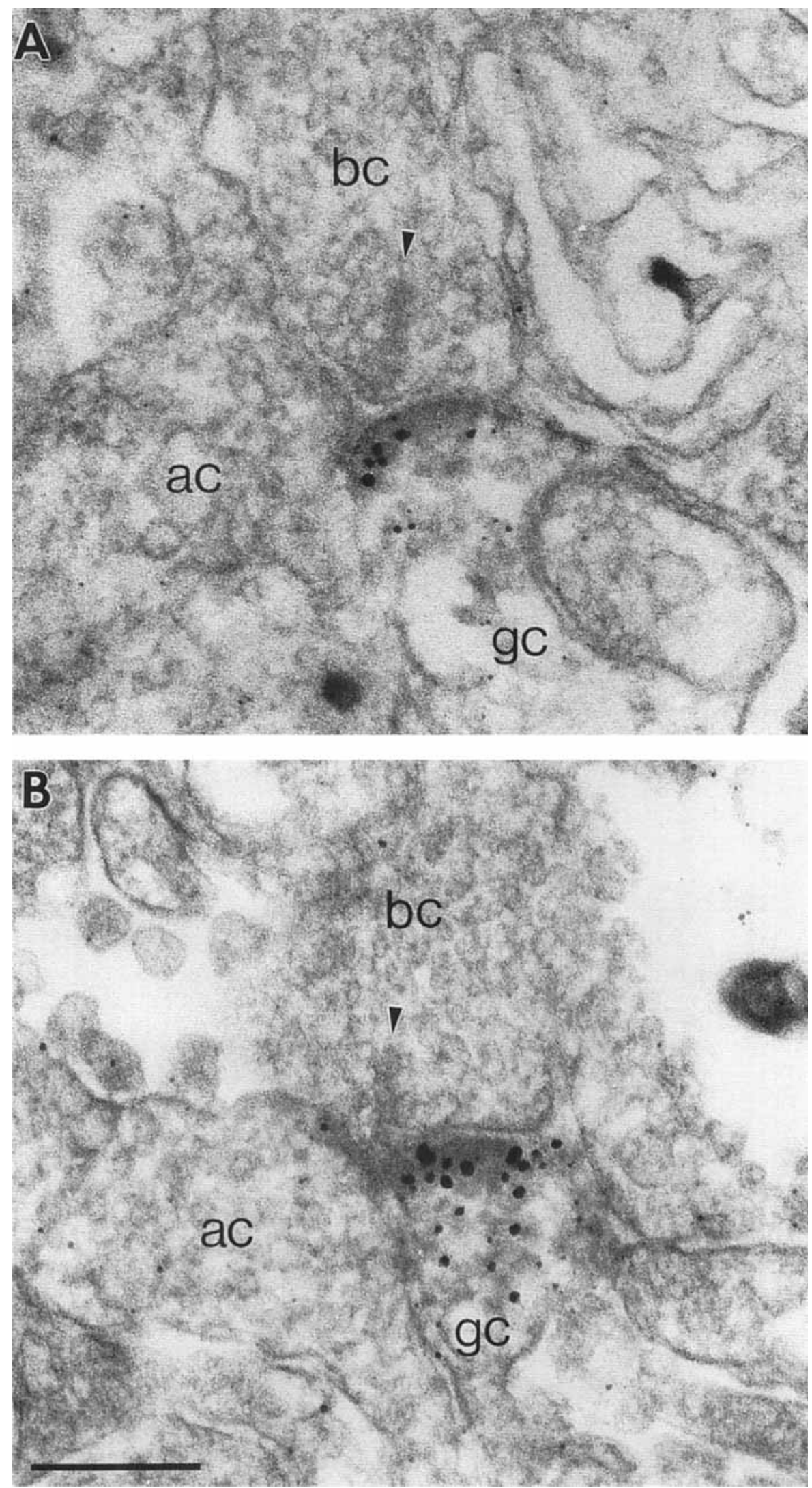

Fig. 3. Electron microscopic localization of NMDA receptor subunit NR2A immunoreactivity in vertical sections through the rat retina. In both $\mathbf{A}$ and $\mathbf{B}$, a cone bipolar cell (bc) makes a ribbon synapse on a ganglion cell (gc) and an amacrine cell (ac). Gold-toned and silver- intensified diaminobenzidine reaction product is located at the cytoplasmic face of the postsynaptic membrane density of the ganglion cell. Arrowhead marks the presynaptic ribbon in the cone bipolar cell. Scale bar $=0.2 \mu \mathrm{m}$. 


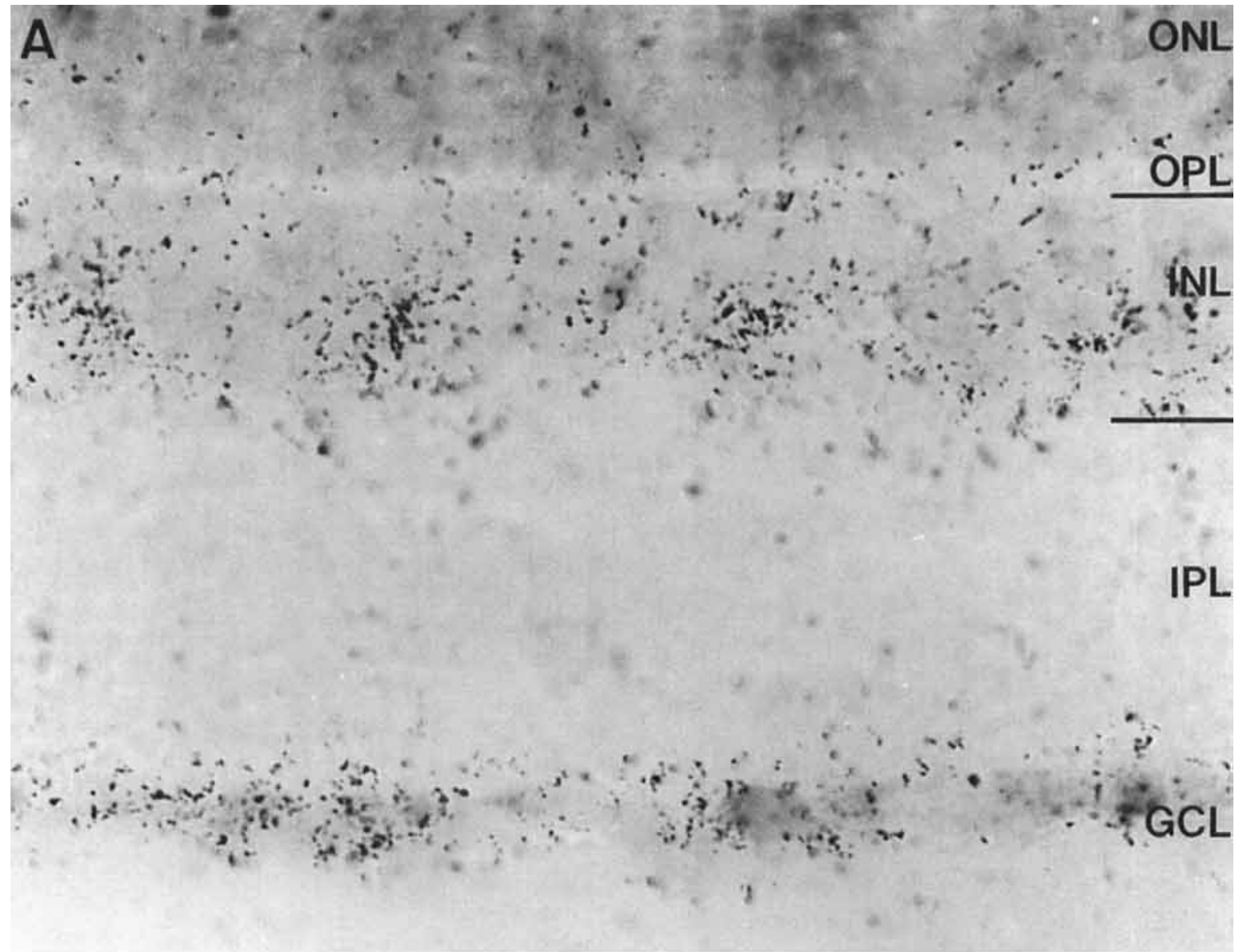

B

ONL

OPL

INL

h
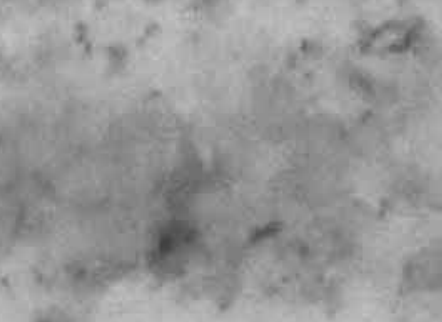

IPL

GCL 
detected (Fig. 5A). The background labeling, seen when the primary antibody was omitted, was quite strong, of a diffuse character, and indistinguishable from the labeling in the experimental sections (not shown). It is therefore not possible to exclude that the NR2A subunit could be expressed at very low levels in this period. At P10, there was sparse but distinctly punctate labeling in the IPL, and it was already organized in two bands that could be clearly separated from areas of lower intensity of labeling (Fig. 5B). In the corresponding control sections, there was moderately strong, diffuse background labeling in the IPL (Fig. 1C) indistinguishable from the labeling in the experimental sections prior to P10 (compare Figs. 5A and 1C).

Starting from $P 10$, the density of labeled puncta rapidly increased (Fig. 5B-D), and, at the time of eye-opening, P14 or P15, the IPL exhibited already quite strong punctate labeling organized in two bands (Fig. 5D). The intensity and pattern of labeling increased in a monotonic fashion from the level at P10, until adult levels were reached at about 3 weeks after birth (not shown). No transient expression of the NR2A subunit in other areas of the retina than the IPL was observed.

\section{DISCUSSION \\ Expression of the NR2A subunit in the retina}

The combined results from the in situ hybridization and the light and electron microscopic studies suggest that the majority of ganglion cells but only a subset of amacrine cells express the NR2A subunit. From recombinant expression studies, it is known that the different types of NR2 subunits (A-D) must be coexpressed with the NR1 subunit in order to be responsive to NMDA receptor agonists and that the resulting receptor complexes differ in their kinetic, pharmacological, and biochemical properties (Kutsuwada et al., 1992; Meguro et al., 1992; Monyer et al., 1992; Mori et al., 1993). Therefore, it is likely that the NR1 subunit is also present at the synaptic sites labelled here with an antibody against the NR2A subunit. However, because NR1 subunits can also combine with other NR2 subunits, one would expect their distribution in the retina to be more widespread as recently confirmed by Brandstätter et al. (1994) and Watanabe et al. (1994).

A point to consider is whether the observed distribution of NR2A is sufficient to account for known physiological effects of NMDA receptor agonists and antagonists in the retina. Electrophysiological studies indicate the presence of NMDA receptors on all on- and off-center brisk sustained (X) and brisk transient ( $\mathrm{Y}$ ) ganglion cells in the cat retina, although NMDA antagonists seem to have only limited effects on visual responses (Boos et al., 1990). In the rabbit, there is also physiological evidence of NMDA receptors on all ganglion cells (Bloomfield and Dowling, 1985b; Massey and Miller, 1988, 1990) and NMDA antagonists have a

Fig. 4. A: Autoradiographic localization of NR2A mRNA in a vertical cryostat section of the rat retina. NR2A mRNA is found in virtually all cells in the ganglion cell layer and in a subset of cells in the innermost part of the inner nuclear layer. B: Absence of labeling when the incubation included a 20 -fold excess of unlabeled probe in addition to labeled probe. Counterstained with toluidine blue. Borders of INL indicated by horizontal lines. ONL, outer nuclear layer; OPL, outer plexiform layer; INL, inner nuclear layer; IPL, inner plexiform layer; GCL, ganglion cell layer. Scale bar $=30 \mu \mathrm{m}$. clear, although relatively weak, suppressive action on the visual response (Massey and Miller, 1990). In the monkey, Cohen and Miller (1994) recently reported that all ganglion cells recorded could be excited by NMDA and that the light-evoked response could be moderately suppressed by NMDA antagonists.

In recordings from dissociated ganglion cells from rat retina, Aizenman et al. (1988) found that NMDA-evoked inward currents were practically abolished by the presence of $1 \mathrm{mM} \mathrm{Mg}{ }^{2+}$ in the extracellular fluid. This is consistent with our results because coexpression of NR1 and NR2A results in receptors with high sensitivity to $\mathrm{Mg}^{2+}$ (Kutsuwada et al., 1992; Meguro et al., 1992; Monyer et al., 1992). Aizenman et al. (1988) detected NMDA-evoked currents in only $68 \%$ of dissociated cells. Our finding that the immunoreactivity is localized on ganglion cell dendrites in the IPL suggests that the absence of NMDA responses in some dissociated cells could be an artefact due to loss of dendrites during the dissociation procedure.

Because NMDA receptors do not seem to be differentially involved with regard to the excitatory input to on- and off-center ganglion cells, on- and off-stratifying ganglion cells may account for significant parts of the two major bands of punctate labeling in the IPL. It is known that the dendrites of off-center ganglion cells stratify closer to the INL, whereas the dendrites of on-center cells stratify closer to the ganglion cell layer (Nelson et al., 1978; Bloomfield and Miller, 1986; Watanabe and Rodieck, 1989; see also Peichl et al., 1987). In the rat, there is also evidence for two stratification levels (Bunt, 1976; Famiglietti and Vaughan, 1981; Peichl, 1989), although it has not yet been demonstrated physiologically that they correspond to on- and off-center cells.

For amacrine cells in the mammalian retina, the evidence for an involvement of NMDA receptors in the synaptic input from bipolar cells is more limited. Boos et al. (1990) suggested that some GABAergic (gamma-aminobutyric acidergic) amacrine cells in cat retina might express NMDA receptors. In the rabbit retina, Massey and Miller (1988) recorded from unidentified amacrine cells that could be excited by NMDA, and Linn and Massey (1991) found evidence of NMDA receptors on cholinergic amacrine cells. This is consistent with the expression of the NR2A subunit mRNA by virtually all neurons in the ganglion cell layer (Fig. 4). Many of these cells are displaced amacrines, some of which are cholinergic (Voigt, 1986). Although we did not observe immunolabeling of processes positively identified as belonging to amacrine cells, the results from the in situ hybridization strongly suggest that some amacrine cells express the NR2A subunit. Accordingly, it might be expected that immunoreactivity for NR2A should also be detected at some cone bipolar cell-to-amacrine cell synapses. Whether the subset of amacrine cells in the INL that expressed NR2A mRNA consists of one or more populations of amacrine cells, remains to be investigated. The preferred location of the NMDA receptors at profiles postsynaptic to cone bipolar ribbon synapses is not surprising because cone bipolar cells are thought to release glutamate and the vast majority of conventional synapses in the IPL are glycinergic or GABAergic amacrine synapses (reviewed by Vaney, 1990).

Because there was only weak labeling in the innermost part of the IPL, it is unlikely that the NR2A subunit is abundant at the synapses made by rod bipolar cells that have their terminals in this region (Kolb and Famiglietti, 1974; Famiglietti and Kolb, 1975; Strettoi et al., 1990; 

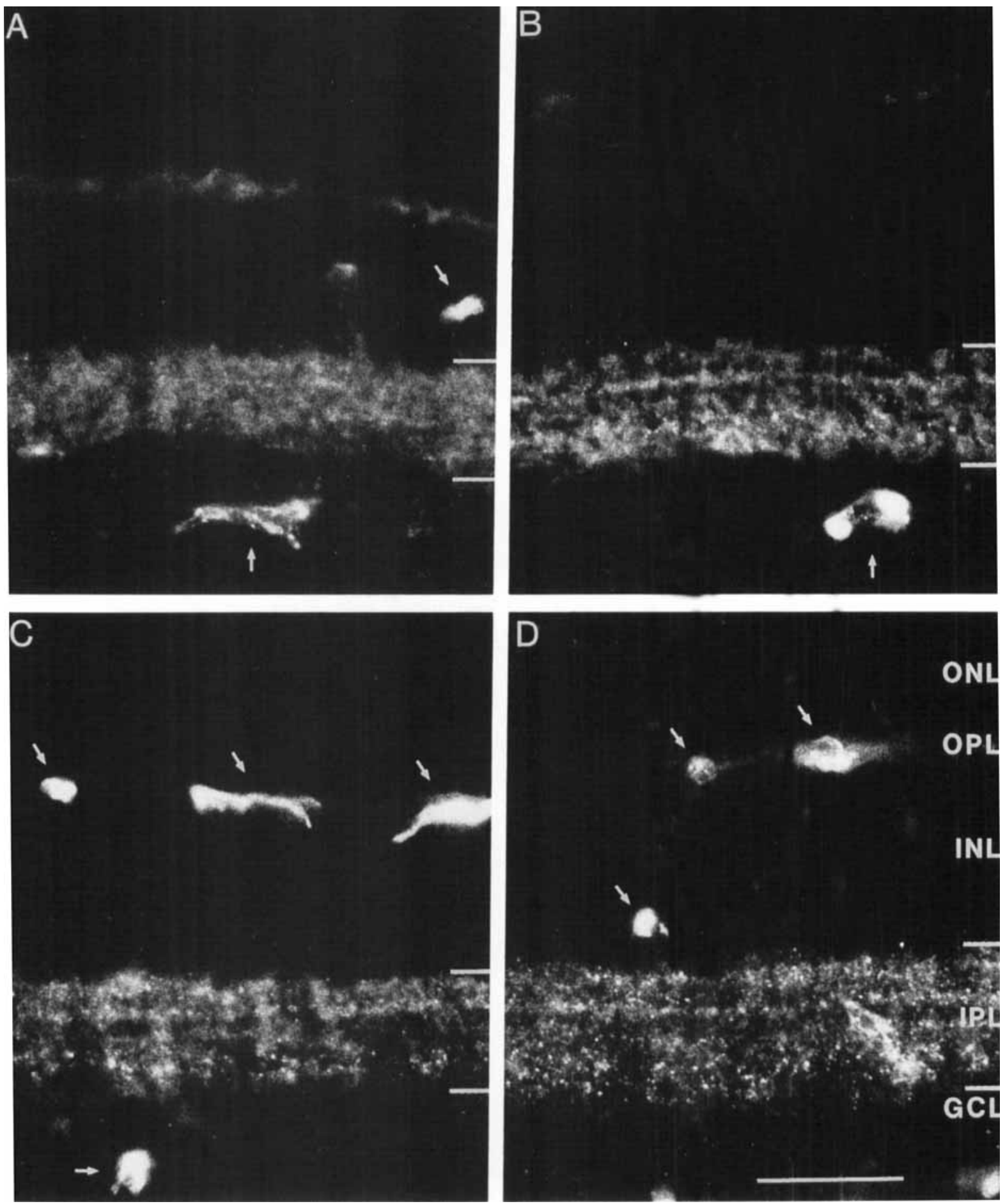

Fig. 5. Localization of NMDA receptor subunit NR2A immunoreactivity in vertical sections of the rat retina during development. At P9 (A) no punctate label is present. At P10 (B), weak and sparse punctate labeling can be observed in the inner plexiform layer with evidence of organization in two bands. At P12 (C) and P14 (D), punctate labeling

Grünert and Martin, 1991; Chun et al., 1993). Correspondingly, the rat AII amacrine cell, generally one of the cells in the pair of amacrines innervated by a rod bipolar cell, has been found by combined electrophysiological and pharmaco- increases in both intensity and density of distribution. Border of the inner plexiform layer are indicated by horizontal lines. Arrows point to stained blood vessels. ONL, outer nuclear layer; OPL, outer plexiform layer; INL, inner nuclear layer; IPL, inner plexiform layer; GCL, ganglion cell layer. Scale bar $=30 \mu \mathrm{m}$.

logical experiments not to express NMDA receptors (Boos et al., 1993).

The lack of immunofluorescence in the OPL of rat, rabbit, and monkey retina is consistent with previous 
physiological evidence that the output from the photoreceptors is mediated via ionotropic non-NMDA receptors (to horizontal cells and off-cone bipolars; Slaughter and Miller, 1983a,b; Bloomfield and Dowling, 1985a; Massey and Miller, 1987) and metabotropic receptors (to rod bipolars and on-cone bipolars; Slaughter and Miller, 1981; Bloomfield and Dowling, 1985a; Müller et al., 1988; Yamashita and Wässle, 1991). However, we unexpectedly observed sparse but distinctly punctate labeling in the OPL of the cat retina (Fig. 2C). This could suggest that part of the input to bipolar or horizontal cells in the cat is mediated by NMDA receptors consistent with physiological findings in some fish retinas (Ariel et al., 1986; O'Dell and Christensen, 1986). Alternatively, the labeling might be related to the presence of vesicles and sometimes even ribbons in dendritic processes of cone bipolars in the OPL (Kolb, 1977) or to the presence of inverted bipolar axon terminals making ribbon synapses in the OPL (Kolb and West, 1977).

\section{Differential localization at postsynaptic targets of cone bipolar cells}

The NR2A subunit was differentially distributed at the profiles postsynaptic to cone bipolar ribbon synapses with one profile being positive and the other negative (Fig. 3). This result is suggestive of an important principle for mechanisms of signal processing in the central nervous system. Both postsynaptic cells receive the same input signal from the cone bipolar terminal, but, because they are equipped with different transmitter receptors, the signal will be processed differently. From our results, we cannot know whether the unstained profile employs only nonNMDA receptors or whether it employs NMDA receptors with subunits other than the NR2A. However, because postsynaptic amacrine cells at bipolar cell dyads quite often provide a reciprocal synapse back onto the bipolar cell, there could be an interesting molecular specification: cells that make reciprocal synapses express different receptors than cells that do not make such synapses.

\section{Synaptic vs. extrasynaptic localization}

The punctate character of immunofluorescence, similar to that previously observed with antibodies against glycine receptors (Grünert and Wässle, 1993), indicates that the receptor is distributed in an aggregate manner most likely corresponding to a synaptic localization. Although light microscopic observations cannot prove that the punctate labeling corresponds to staining of receptors located at synapses, this hypothesis is strengthened by our results from the immunoelectron microscopy. The reaction product was exclusively located postsynaptically, and we never observed reaction product at extrasynaptic plasma membranes.

The strict synaptic localization of the NR2A subunit is relevant for the interpretation of the slow time course of NMDA receptor evoked currents. Although the ion channel is an integral part of the NMDA receptor complex, the evoked currents have remarkably slow rise and decay rates (Collingridge et al., 1988; Forsythe and Westbrook, 1988). One possible explanation is that synaptically released glutamate must diffuse to extrasynaptic NMDA receptors (see Hestrin et al., 1990). However, recent investigations have provided strong evidence that the time course of NMDAevoked currents can be accounted for by the kinetic properties of the NMDA channels themselves (Hestrin et al., 1990; Lester et al., 1990; Monyer et al., 1992). This is consistent with our results, showing that, at least for synapses in the IPL, extrasynaptic localization of receptors cannot be invoked to explain slow rise times of NMDA current.

Based on hydrophobicity analysis of the receptor amino acid sequence, it was initially proposed that NMDA receptor subunits have four transmembrane spanning regions and that both the $\mathrm{N}$-terminal and the $\mathrm{C}$-terminal domains are located extracellularly (Moriyoshi et al., 1991; Kutsuwada et al., 1992; Meguro et al., 1992; Monyer et al., 1992) in accordance with the current model for ligand-gated ion channels (reviewed by Betz, 1990). However, the immunoreactivity caused by the anti-NR2A-C-terminus antibody was located at the cytoplasmic face of the postsynaptic density, not at the extracellular face (see Fig. 3), suggesting that the C-terminal domain is located intracellularly. This finding resembles previous ultrastructural observations with antibodies directed against AMPA-receptor subunits (Petralia and Wenthold, 1992; Martin et al., 1993; Molnar et al., 1993) and supports C-terminal phosphorylation studies that suggest that the topological model for NMDA receptors has to be revised (Tingley et al., 1993).

\section{Development of glutamatergic circuitry in the IPL}

We found evidence of punctate labeling in the IPL of rat retina starting from $\mathrm{P} 10$ (Fig. 5). At this early stage, the labeling was sparse with relatively few puncta. The pattern of labeling with regard to distribution and intensity reached adult levels at about 3 weeks postnatally. These findings are consistent with a recent developmental in situ hybridization study in the mouse retina where NR2A mRNA was detected at P7 and P14 but not at P1 (Watanabe et al., 1994). We also observed a gradual transition from the neonatal to the adult pattern similar to that observed by in situ hybridization in the mouse brain and retina (Watanabe et al., 1992, 1994). These results raise the question whether the NR2A subunit could play a specific role in the establishment of excitatory connections in the IPL.

The relationship between the first occurrence of punctate labeling and synapse formation in the IPL is somewhat surprising. Previous investigations of synaptogenesis in the rat report that a few conventional synapses can be observed at P11 and P12, whereas ribbon synapses are first observed at P13 (Horsburgh and Sefton, 1987). Using criteria for classification of synapses in the adult, the conventional synapses would be considered to arise from amacrine cells and the ribbon synapses from bipolar cells (Dowling and Boycott, 1966; Dubin, 1970). Punctate labeling was therefore observed shortly before the occurrence of synapses from bipolar cells, presumably the only elements presynaptic to NMDA receptors in the IPL. There are at least two explanations for this potential discrepancy. First, some of the earliest conventional synapses could arise from bipolar cells if the ribbons themselves form only after synaptic vesicles are present (cf. Nishimura and Rakic, 1987). Second, at the earliest stages, many of the fluorescent puncta could correspond to aggregates of receptors but without any corresponding presynaptic elements. Postsynaptic aggregates of receptors without presynaptic elements have been described from developmental studies on the neuromuscular system (Fischbach and Cohen, 1973; Hartzell and Fambrough, 1973). In our case, the question cannot be settled by light microscopy. Because recognition of the antigen was very fixation sensitive, the fixation time was only 4-5 minutes in the developmental experiments. We did 
not attempt electron microscopic examination because this would have required considerably longer fixation times.

Whereas the distribution and expression of the NR2A subunit in the adult retina could, in principle, be sufficient to account for the known effects of NMDA receptor agonists and antagonists on ganglion cells, this does not seem to be the case for the neonatal retina. In ganglion cells of the rat, NMDA can evoke currents as early as P4 (Rörig and Grantyn, 1993b). There is also evidence of glutamatergic input to retinal ganglion cells as early as P5, possibly by vesicular release from growth cones, but this seems to be mediated entirely by non-NMDA receptors (Rörig and Grantyn, 1993a). It is possible that the early responses to NMDA are mediated by diffusely distributed receptors similar to the development of the GABAergic circuitry, where responses to exogenously applied GABA could be evoked before synaptically mediated GABAergic currents could be observed (P5; Rörig and Grantyn, 1993a). Alternatively, the effects of NMDA could be mediated by heteromeric assemblies containing NR2 subunits other than NR2A, most likely NR2B, which, in mouse retina, is expressed at increasing levels from embryonic stages (Watanabe et al., 1994).

In other regions of the vertebrate central nervous system, NMDA receptors have been implicated in pruning of exuberant connectivity during development (see, e.g., Hahm et al., 1991). In the retina, ganglion cells go through a transient phase with profuse branching and an excessive number of spine-like dendritic processes (cat: Dann et al., 1988; Ramoa et al., 1988; rat: Yamasaki and Ramoa, 1993; hamster: Lau et al., 1992b). It has been suggested that these spine-like processes are the initial targets for synaptic input from bipolar and amacrine cells, but this has not been confirmed at the ultrastructural level (Wong et al., 1992). There is evidence, however, that intraocular injection of an NMDA antagonist prevents the elimination of the spinelike processes on some ganglion cells in hamster retina (Lau et al., 1992a). Because the number of these processes in rat reaches maximum at $\mathrm{P} 12$ and declines thereafter (Yamasaki and Ramoa, 1993), our results are compatible with a role for the NR2A subunit in this developmental process.

Initially, the dendritic processes of ganglion cells are not only profuse, but they are also diffusely distributed and only gradually become confined to the IPL, first bistratified and finally unistratified, with processes restricted to either the outer or inner part of the IPL, corresponding to off-center or on-center responses, respectively. The refinement occurs at the time when ribbon synapses form in the IPL (Maslim and Stone, 1986, 1988). If the ganglion cells receive functional connections from bipolar cells during the bistratified stage, one could imagine that a use-dependent mechanism is involved in the transition to a unistratified pattern. Interestingly, Bodnarenko and Chalupa (1993) recently reported that intraocular injections of APB in neonatal kittens, supposedly blocking the activity of onbipolar cells, disrupted stratification of ganglion cell dendrites. Unfortunately, the sequential development of stratification has been described in detail only for the cat (Maslim and Stone, 1988; cf. also Dann et al., 1988; Ramoa et al., 1988 ), and no information is available for the rat other than a remark by Maslim et al. (1986) that the segregation of ganglion cell dendrites occurs from P6 to P14. If this is correct, it leaves open the possible involvement of the NR2A receptor subunit, clearly expressed during the latter half of this period.

\section{ACKNOWLEDGMENTS}

We thank Dr. U. Greferath for advice on the in situ hybridization technique, W. Hofer for assistance with electron microscopy, and Dr. U. Grünert for supplying the sections from monkey retina. The project was supported by the Alexander von Humboldt-Stiftung (E.H.) and grants from the Deutsche Forschungsgemeinschaft (SFB 269/B4 and SFB 317/B9) and the Bundesministerium für Forschung und Technologie (BCT 364 AZ 321/7291).

\section{LITERATURE CITED}

Aizenman, E., M.P. Frosch, and S.A. Lipton (1988) Responses mediated by excitatory amino acid receptors in solitary retinal ganglion cells from rat. J. Physiol. 396:75-91.

Ariel, M., S.C. Mangel, and J.E. Dowling (1986) N-Methyl D-aspartate acts as an antagonist of the photoreceptor transmitter in the carp retina. Brain Res. 372:143-148.

Bettler, B., J. Boulter, I. Hermans-Borgmeyer, A. O'Shea-Greenfield, E.S. Deneris, C. Mol], U. Borgmeyer, M. Hollmann, and S. Heinemann (1990) Cloning of a novel glutamate receptor subunit, GluR5: Expression in the nervous system during development. Neuron 5:583-595.

Bettler, B., J. Egebjerg, G. Sharma, G. Pecht, I. Hermans-Borgmeyer, C. Moll, C.F. Stevens, and S. Heinemann (1992) Cloning of a putative glutamate receptor: A low affinity kainate-binding subunit. Neuron 8:257-265.

Betz, H. (1990) Ligand-gated ion channels in the brain: The amino acid receptor superfamily. Neuron 5:383-392.

Bloomfield, S.A., and J.E. Dowling (1985a) Roles of aspartate and glutamate in synaptic transmission in rabbit retina. I. Outer plexiform layer. J. Neurophysiol. 53:699-713.

Bloomfield, S.A., and J.E. Dowling (1985b) Roles of aspartate and glutamate in synaptic transmission in rabbit retina. II. Inner plexiform layer. J. Neurophysiol. 53:714-725.

Bloomfield, S.A., and R.F. Miller (1986) A functional organization of on and off pathways in the rabbit retina. J. Neurosci. $6: 1-13$.

Bodnarenko, S.R., and L.M. Chalupa (1993) Stratification of on and off ganglion cell dendrites depends on glutamate-mediated afferent activity in the developing retina. Nature 364:144-146.

Boos, R., F. Müller, and H. Wässle (1990) Actions of excitatory amino acids on brisk ganglion cells in the cat retina. J. Neurophysiol. 64: 1368-1379.

Boos, R., H. Schneider, and H. Wässle (1993) Voltage- and transmitter-gated currents of AII-amacrine cells in a slice preparation of the rat retina. J. Neurosci. 13:2874-2888.

Boulter, J., M. Hollmann, A. O'Shea-Greenfield, M. Hartley, E. Deneris, C. Maron, and S. Heinemann (1990) Molecular cloning and functional expression of glutamate receptor subunit genes. Science 249:1033-1037.

Brandstätter, J.H., E. Hartveit, M. Sassoè-Pognetto, and H. Wässle (1994) Expression of NMDA- and high-affinity kainate receptor subunit mRNAs in the adult rat retina. Eur. J. Neurosci, 6: 1100-1112.

Bunt, A.H. (1976) Ramification patterns of ganglion cell dendrites in the retina of the albino rat. Brain Res. 103:1-8.

Burnashev, N., H. Monyer, P.H. Seeburg, and B. Sakmann (1992) Divalent ion permeability of AMPA receptor channels is dominated by the edited form of a single subunit. Neuron 8:189-198.

Chun, M.-H., S.-H. Han, J.-W. Chung, and H. Wässle (1993) Electron microscopic analysis of the rod pathway of the rat retina. J. Comp. Neurol. 332:421-432.

Cohen, E.D., and R.F. Miller (1994) The role of NMDA and non-NMDA excitatory amino acid receptors in the functional organization of primate retinal ganglion cells. Vis. Neurosci. 11:317-332.

Coleman, P.A., and R.F. Miller (1988) Do N-methyl-D-aspartate receptors mediate synaptic responses in the mudpuppy retina? J. Neurosci. 8:4728-4733.

Collingridge, G.L., C.E. Herron, and R.A.J. Lester (1988) Synaptic activation of N-methyl-D-aspartate receptors in the Schaffer collateral-commissural pathway of rat hippocampus. J. Physiol. 399:283-300.

Copenhagen, D.R., and C.E. Jahr (1989) Release of endogenous excitatory amino acids from turtle photoreceptors. Nature 341:536-539.

Dann, J.F., E.H. Buhl, and L. Peichl (1988) Postnatal dendritic maturation of alpha and beta ganglion cells in cat retina. J. Neurosci. 8:1485-1499. 
Dixon, D.B., and D.R. Copenhagen (1992) Two types of glutamate receptors differentially excite amacrine cells in the tiger salamander retina. $J$ Physiol. 449:589-606.

Dowling, J.E., and B.B. Boycott (1966) Organization of the primate retina: Electron microscopy. Proc. R. Soc. London [Biol.] 166:80-111.

Dubin, M.W. (1970) The inner plexiform layer of the vertebrate retina: A quantitative and comparative electron microscopic analysis. J. Comp. Neurol. 140:479-506.

Egebjerg, J., B. Bettler, I. Hermans-Borgmeyer, and S. Heinemann (1991) Cloning of a cDNA for a glutamate receptor subunit activated by kainate but not AMPA. Nature 351:745-748.

Famiglietti, E.V., and H. Kolb (1975) A bistratified amacrine cell and synaptic circuitry in the inner plexiform layer of the retina. Brain Res. 84:293-300.

Famiglietti, E.V., and J.E. Vaughan (1981) Golgi-impregnated amacrine cells and GABAergic retinal neurons: A comparison of dendritic, immunocytochemical and histochemical stratification in the inner plexiform layer of rat retina. J. Comp. Neurol. 197:129-140.

Fischbach, G.D., and S.A. Cohen (1973) The distribution of acetylcholine sensitivity over uninnervated and innervated muscle fibers grown in cell culture. Dev. Biol. 31:147-162.

Forsythe, I.D., and G.L. Westbrook (1988) Slow excitatory postsynaptic currents mediated by N-methyl-D-aspartate receptors on cultured mouse central neurones. J. Physiol. 396:515-533.

Gottesman, J., and R.F. Miller (1992) Pharmacological properties of Nmethyl-D-aspartate receptors on ganglion cells of an amphibian retina. $\mathrm{J}$. Neurophysiol. 68:596-604.

Grünert, U., and P.R. Martin (1991) Rod bipolar cells in the macaque monkey retina: Immunoreactivity and connectivity. J. Neurosei. 11:27422758.

Grünert, U., and H. Wässle (1993) Immunocytochemical localization of glycine receptors in the mammalian retina. J. Comp. Neurol. 335:523537.

Hahm, J.-O., R.B. Langdon, and M. Sur (1991) Disruption of retinogeniculate afferent segregation by antagonists to NMDA receptors. Nature $351: 568-570$

Hamassaki-Britto, D.E., I. Hermans-Borgmeyer, S. Heinemann, and T.E. Hughes (1993) Expression of glutamate receptor genes in the mammalian retina: The localization of GluR1 through GluR7 mRNAs. J. Neurosci. 13:1888-1898.

Hartzell, H.C., and D.M. Fambrough (1973) Acetylcholine receptor production and incorporation into membranes of developing muscle fibers. Dev Biol. 30:153-165.

Herb, A., N. Burnashev, P. Werner, B. Sakmann, W. Wisden, and P.H. Seeburg (1992) The KA-2 subunit of excitatory amino acid receptor shows widespread expression in brain and forms ion channels with distantly related subunits. Neuron $8: 775-785$.

Hestrin, S., P. Sah, and R.A. Nicoll (1990) Mechanisms generating the time course of dual component excitatory synaptic currents recorded in hippocampal slices. Neuron 5:247-253.

Hollmann, M., A. O'Shea-Greenfield, S.W. Rogers, and S. Heinemann (1989) Cloning by functional expression of a member of glutamate receptor family. Nature 342:643-648.

Hollmann, M., M. Hartley, and S. Heinemann. (1991) $\mathrm{Ca}^{2+}$ permeability of KA-AMPA-gated glutamate receptor channels depends on subunit composition. Science 252:851-853.

Horsburgh, G.M., and A.J. Sefton (1987) Cellular degeneration and synaptogenesis in the developing retina of the rat. J. Comp. Neurol. 263:553566.

Houamed, K.M., J.L. Kuijper, T.L. Gilbert, B.A. Haldeman, P.J. O'Hara E.R. Mulvihill, W. Almers, and F.S. Hagen (1991) Cloning, expression, and gene structure of a $\mathrm{G}$ protein-coupled glutamate receptor from rat brain. Science 252:1318-1321.

Hughes, T.E., I. Hermans-Borgmeyer, and S. Heinemann (1992) Differential expression of glutamate receptor genes (GluR1-5) in the rat retina. Vis. Neurosci. 8:49-55

Ikeda, K., M., Nagasawa, H. Mori, K. Araki, K. Sakimura, M. Watanabe, Y. Inoue, and M. Mishina (1992) Cloning and expression of the E4 subunit of the NMDA receptor channel. FEBS Lett. 313:34-38.

Ishii, T., K. Moriyoshi, H. Sugihara, K. Sakurada, H. Kadotani, M. Yokoi, C Akazawa, R. Shigemoto, N. Mizuno, M. Masu, and S. Nakanishi (1993) Molecular characterization of the family of the N-methyl-D-aspartate receptor subunits. J. Biol, Chem. 268:2836-2843.

Johnson, J.W., and P. Ascher (1987) Glycine potentiates the NMDA response in cultured mouse brain neurons. Nature 325:529-531
Keinänen, K., W. Wisden, B. Sommer, P. Werner, A. Herb, T.A. Verdoorn, B. Sakmann, and P.H. Seeburg (1990) A family of AMPA-selective glutamate receptors. Science 249:556-560.

Kolb, H. (1977) The organization of the outer plexiform layer in the retina of the cat: Electron microscopic observations. J. Neurocytol. 6:131-153.

Kolb, H. (1979) The inner plexiform layer in the retina of the cat: Electron microscopic observations. J. Neurocytol. 8:295-329.

Kolb, H., and E.V. Famiglietti (1974) Rod and cone pathways in the inner plexiform layer of the cat retina. Science $186: 47-49$.

Kolb, H., and R.W. West (1977) Synaptic connections of the interplexiform cell in the retina of the cat. J. Neurocytol. 6:155-170.

Kutsuwada, T., N. Kashiwabuchi, H. Mori, K. Sakimura, E. Kushiya, K. Araki, H. Meguro, H. Masaki, T. Kumanishi, M. Arakawa, and M. Mishina (1992) Molecular diversity of the NMDA receptor channel. Nature 358:36-41.

Lau, K.C., K.-F. So, and D. Tay (1992a) APV prevents the elimination of transient dendritic spines on a population of retinal ganglion cells. Brain Res. 595:171-174.

Lau, K.C., K.-F. So, and D. Tay (1992b) Postnatal development of type I retinal ganglion cells in hamsters: A Lucifer Yellow study. J. Comp. Neurol. 315:375-381.

Leranth, C., and V.M. Pickel (1989) Electron microscopic preembedding double-immunostaining methods. In L. Heimer and L. Záborszky (eds): Neuroanatomical Tract-Tracing Methods 2. Recent Progress. New York: Plenum Press, pp. 129-172.

Lester, R.A.J., J.D. Clements, G.L. Westbrook, and C.E. Jahr (1990) Channel kinetics determine the time course of NMDA receptor-mediated synaptic currents. Nature 346:565-567.

Linn, D.M., and S.C. Massey (1991) Acetylcholine release from the rabbit retina mediated by NMDA receptors. J. Neurosci. 11:123-133.

MacDermott, A.B., M.L. Mayer, G.L. Westbrook, S.J. Smith, and J.L. Barker (1986) NMDA-receptor activation increases cytoplasmic calcium concentration in cultured spinal cord neurones. Nature 321:519-522.

Martin, L.J., C.D. Blackstone, A.I. Levey, R.L. Huganir, and D.L. Price (1993) AMPA glutamate receptor subunits are differentially distributed in rat brain. Neuroscience 53:327-358.

Maslim, J., and J. Stone (1986) Synaptogenesis in the retina of the cat. Brain Res. 373:35-48

Maslim, J., and J. Stone (1988) Time course of stratification of the dendritic fields of ganglion cells in the retina of the cat. Dev. Brain Res. 44:87-93.

Maslim, J., M. Webster, and J. Stone (1986) Stages in the structural differentiation of retinal ganglion cells. J. Comp. Neurol. 254:382-402.

Massey, S.C. (1990) Cell types using glutamate as a neurotransmitter in the vertebrate retina. In N.N. Osborne and G.J. Chader (eds): Progress in Retinal Research. Oxford: Pergamon Press, Vol. 9, pp. 399-425.

Massey, S.C., and R.F. Miller (1987) Excitatory amino acid receptors of rod-and cone-driven horizontal cells in the rabbit retina. J. Neurophysiol. 57:645-659.

Massey, S.C., and R.F. Miller (1988) Glutamate receptors of ganglion cells in the rabbit retina: Evidence for glutamate as a bipolar cell transmitter. J. Physiol. 405:635-655.

Massey, S.C., and R.F. Miller (1990) N-methyl-D-aspartate receptors of ganglion cells in rabbit retina. J. Neurophysiol. 63:16-30.

Masu, M., Y. Tanabe, K. Tsuchida, R. Shigemoto, and S. Nakanishi (1991) Sequence and expression of a metabotropic glutamate receptor. Nature 349:760-765.

Meguro, H., H. Mori, K. Araki, E. Kushiya, T. Kutsuwada, M. Yamazaki, T. Kumanishi, M. Arakawa, K. Sakimura, and M. Mishina (1992) Functional characterization of a heteromeric NMDA receptor channel expressed from cloned cDNAs. Nature 357:70-74.

Mittman, S., W.R. Taylor, and D.R. Copenhagen (1990) Concomitant activation of two types of glutamate receptor mediates excitation of salamander retinal ganglion cells. J. Physiol. 428:175-197.

Molnar, E., A. Baude, S.A. Richmond, P.B. Patel, P. Somogyi, and R.A.J. McIlhinney (1993) Biochemical and immunocytochemical characterization of antipeptide antibodies to a cloned GluR1 glutamate receptor subunit: Cellular and subcellular distribution in the rat forebrain. Neuroscience 53:307-326.

Monaghan, D.T., R.J. Bridges, and C.W. Cotman (1989) The excitatory amino acid receptors: Their classes, pharmacology, and distinct properties in the function of the central nervous system. Annu. Rev. Pharmacol. Toxicol. 29:365-402.

Monyer, H., R. Sprengel, R. Schoepfer, A. Herb, M. Higuchi, H. Lomeli, N. Burnashev, B. Sakmann, and P.H. Seeburg (1992) Heteromeric NMDA 
receptors: Molecular and functional distinction of subtypes. Science 256: 1217-1221.

Mori, H., T. Yamakura, H. Masaki, and M. Mishina (1993) Involvement of the carboxyl-terminal region in modulation by TPA of the NMDA receptor channel. Neuroreport 4:519-522.

Moriyoshi, K., M. Masu, T. Ishii, R. Shigemoto, N. Mizıno, and S. Nakanishi (1991) Molecular cloning and characterization of the rat NMDA receptor. Nature 354:31-37.

Müller, F., H. Wässle, and T. Voigt (1988) Pharmacological modulation of the rod pathway in the cat retina. J. Neurophysiol. 59:1657-1672.

Müller, F., U. Greferath, H. Wässle, W. Wisden, and P.H. Seeburg (1992) Glutamate receptor expression in the rat retina. Neurosci. Lett. 138:179182.

Nakanishi, N., N.A. Shneider, and R. Axel (1990) A family of glutamate receptor genes: Evidence for the formation of heteromultimeric receptors with distinct channel properties. Neuron 5:569-581.

Nelson, R., E.V. Famiglietti, and H. Kolb (1978) Intracellular staining reveals different levels of stratification for on- and off-center ganglion cells in cat retina. J. Neurophysiol. 41:472-483.

Nishimura, Y., and P. Rakic (1987) Development of the Rhesus monkey retina: II. A three-dimensional analysis of the sequences of synaptic combinations in the inner plexiform layer. J. Comp. Neurol. 262:290-313.

Nowak, L., P. Bregestovski, P. Ascher, A. Herbet, and A. Prochiantz (1984) Magnesium gates glutamate-activated channels in mouse central neurones. Nature $307: 462-465$.

O'Dell, T., and B.N. Christensen (1986) N-Methyl-D-aspartate receptors coexist with kainate and quisqualate receptors on single isolated catfish horizontal cells. Brain Res. 381:359-362.

Peichl, L. (1989) Alpha and delta ganglion cells in the rat retina. J. Comp. Neurol. 286:120-139.

Peichl, L., E.H. Buhl, and B.B. Boycott (1987) Alpha ganglion cells in the rabbit retina. J. Comp. Neurol. 263:25-41.

Petralia, R.S., and R.J. Wenthold (1992) Light and electron immunocytochemical localization of AMPA-selective glutamate receptors in the rat brain. J. Comp. Neurol. 318:329-354.

Ramoa, A.S., G. Campbell, and C.J. Shatz (1988) Dendritic growth and remodeling of cat retinal ganglion cells during fetal and postnatal development. J. Neurosei. 8:4239-4261.

Rörig, B., and R. Grantyn (1993a) Glutamatergic and GABAergic synaptic currents in ganglion cells from isolated retinae of pigmented rats during postnatal development. Dev. Brain Res. 74:98-110

Rörig, B, and R. Grantyn (1993b) Rat retinal ganglion cells express $\mathrm{Ca}^{2+}$-permeable non-NMDA glutamate receptors during the period of histogenetic cell death. Neurosci. Lett. 153:32-36.

Schoepfer, R. (1993) The pRSET family of $\mathrm{T} 7$ promotor expression vectors for Escherichia coli. Gene 124:83-85.

Slaughter, M.M., and R.F. Miller (1981) 2-Amino-4-phosphonobutyrate: A new pharmacological tool for retina research. Science 211:182-185.

Slaughter, M.M., and R.F. Miller (1983a) An excitatory amino acid antago- nist blocks cone input to sign-conserving second-order retinal neurons. Science 219:1230-1232.

Slaughter, M.M., and R.F. Miller (1983b) The role of excitatory amino acid transmitters in the mudpuppy retina: An analysis with kainic acid and N-methyl aspartate. J. Neurosci. 3:1701-1711.

Strettoi, E., R.F. Dacheux, and E. Raviola (1990) Synaptic connections of rod bipolar cells in the inner plexiform layer of the rabbit retina. J. Comp. Neurol. 295:449-466.

Studier, F.W., A.H. Rosenberg, J.J. Dunn, and J.W. Dubendorff (1990) Use of T7 RNA polymerase to direct expression of cloned genes. In D.V Goeddel (ed): Methods in Enzymology. San Diego: Academic Press, Vol. 185 , pp. $60-89$.

Tachibana, M., and T. Okada (1991) Release of endogenous excitatory amino acids from on-type bipolar cells isolated from the goldfish retina. J. Neurosci. 11:2199-2208.

Tanabe, Y., M. Masu, T. Ishii, R. Shígemoto, and S. Nakanishi (1992) A family of metabotropic glutamate receptors. Neuron 8:169-179.

Tingley, W.G., K.W. Roche, A.K. Thompson, and R.L. Huganir (1993) Regulation of NMDA receptor phosphorylation by alternative splicing of the C-terminal domain. Nature 364:70-73

Vaney, D.I. (1990) The mosaic of amacrine celts in the mammalian retina. In N.N. Osborne and G.J. Chader (eds): Progress in Retinal Research. Oxford: Pergamon Press, Vol. 9, pp. 49-100.

Voigt, T. (1986) Cholinergic amacrine cells in the rat retina. J. Comp. Neurol. 248:19-35

Watanabe, M., and R.W. Rodieck (1989) Parasol and midget ganglion cells of the primate retina. J. Comp. Neurol. 289:434-454.

Watanabe, M., Y. Inoue, K. Sakimura, and M. Mishina (1992) Developmental changes in distribution of NMDA receptor channel subunit mRNAs Neuroreport 3:1138-1140.

Watanabe, M., M. Mishina, and Y. Inoue (1994) Differential distributions of the NMDA receptor channel subunit mRNAs in the mouse retina. Brain Res. 634:328-332.

Werner, P., M. Voigt, K. Keinänen, W. Wisden, and P.H. Seeburg (1991) Cloning of a putative high-affinity kainate receptor expressed predominantly in hippocampal CA3 cells. Nature 351:742-744

Wisden, W., B.J. Morris, and S.P. Hunt (1991) In situ hybridization with synthetic DNA probes. In J. Chad and H. Wheal (eds): Molecular Neurobiology: A Practical Approach. Oxford: IRL Press/Oxford University Press, pp. 205-225.

Wong, R.O.L., R.M. Yamawaki, and C.J. Shatz (1992) Synaptic contacts and the transient dendritic spines of developing retinal ganglion cells. Eur. J. Neurosei. 4:1387-1397.

Yamasaki, E.N., and A.S. Ramoa (1993) Dendritic remodelling of retinal ganglion cells during development of the rat. J. Comp. Neurol. 329:277289 .

Yamashita, M., and H. Wässle (1991) Responses of rod bipolar cells isolated from the rat retina to the glutamate agonist 2-amino-4-phosphonobutyric acid (APB). J. Neurosci. 11:2372-2382 